\title{
Analysis of factors related to the utilization of the community health center by bpjs participants in three puskesmas in Banjarmasin city, 2020
}

\author{
Septy Handayani ${ }^{1}{ }^{*}$ Ruslan Muhyi ${ }^{2}$, Eko Suhartono ${ }^{3}$, Husaini ${ }^{4}$, Meitria Syahadatina Noor ${ }^{5}$ \\ 1, 3, 4,5 Master of Public Health Science, Medical Faculty, Lambung Mangkurat University, South Kalimantan, Indonesia \\ 2 Medical Faculty, Lambung Mangkurat University, South Kalimantan, Indonesia
}

\author{
Keywords \\ Knowledge \\ Facilities \\ Infrastructure \\ Ease of access \\ Utilization of community \\ Health centers
}

Received: 14 January 2020

Accepted: 18 March 2020

Published: 16 June 2020

\begin{abstract}
BPJS Kesehatan provides health services in collaboration with all First Level Health Service Facilities and Advanced Level Health Facilities. Based on BPJS data, the largest use of BPJS is at the Community Health Centers. However, there are health centers with the lowest and decreasing use of BPJS in Banjarmasin, namely Banjarmasin Indah, S. Parman, and Alalak Tengah Community Health Centers. This study analyzes the factors related to the use of Community Health Centers by BPJS patients at 3 Community Health Centers in Banjarmasin City. This research was analytic observational with a cross-sectional design. The population was all patients who visited the Community Health Centers with a consecutive sampling technique of 106 people. The instrument was a questionnaire, data analysis using Multiple Logistic Regression. The results showed that there was a relationship between the level of knowledge and the utilization of Community Health Centers services ( $p$-value 0.000$)$ and PR of 7.619 (95\% CI $3,474-16,710)$, there was a relationship between the facilities and the utilization of Community Health Centers services ( $p$-value 0.000) and PR of 3.920 (CI 1.972-7.792). There is a relationship between infrastructure and Community Health Centers' utilization ( $p$-value 0.001 ) and PR of 2.611 (95\% CI 1.539-4.430). There is a relationship between infrastructure and the utilization of Community Health Centers services ( $p$-value 0.000 ) and a PR value of 7.045 (CI 3.208-15.474). There is a relationship between knowledge, facilities, infrastructure, easy access to health centers using Community Health Centers services ( $p$-value 0.000) in multivariate analysis. There is a relationship between knowledge, facilities, infrastructure, and ease of access using Community Health Centers by BPJS patients in 3 Community Health Centers in Banjarmasin City. The Study has applicability in the public health management field, and originality lies in Factors in the utilization of primary health services by BPJS participants.
\end{abstract}

(C) 2020 The Author(s). Published by TAF Publishing.

\section{INTRODUCTION}

BPJS Kesehatan (Health Social Security Implementing Agency) collaborates with all First Level Health Service Facilities (FKTP) and Advanced Level Health Facilities (FKTL) in implementing health services. Community Health Center (Puskesmas) is one of FKTP that collaborating with BPJS Kesehatan. Community health center (Puskesmas) is the most visited place for outpatients treatment, as many as $37.29 \%$, by Indonesian people to obtain basic services $[1,2,3]$.

Based of the official websiteof BPJS Kesehatan as of November 18, 2016, showed that there were 170.954 .111 people who had registered as BPJS participants and community health center as the most used facility with total of 9.814 people cameas of November 21, 2016 [4]. There were 2 community health centers, with the least visit, identified to experience a decrease in patients visit or utilization.

Based on data obtained from the recapitulation of participant visit in the period of Januray to June 2019, Banjarmasin Indah community health center had a decrease by 36 people in January to June. Likewise, S. Parman community health center experienced a decrease of 45 people in January to June and Alalak Tengah community health center ,although were not the least in the number of visits, experienced a decrease of 42 people in January to June. Mean-

\footnotetext{
${ }^{*}$ corresponding author: Septy Handayani

†email: septyh2@gmail.com
} 
while, the total number of BPJS participants at 3 community health center were 97,225 people, consisted of 12.807 , 23.339, and 61.109 participants from Banjarmasin Indah, S. Parman, and Alalak Tengah community health centers consecutively $[5,6]$.

There are factors related with patient in utilizing health facility. Those factors could be seen from individual's behavior changes. Knowledge is a process of recall and identify objects in particular field that have been studied via five senses [7, 8]. Public knowledge is the first factor of predictive factor. Based on data from Banjarmasin Health Office in 2019, from 26 community health center in Banjarmasin City, BPJS participants who came and used health services for treatment were predominantly primary and junior high school graduates $[1,9]$. According to Banjarmasin City Central Bureau of Statistics in 2019, the percentage of population aged 15 years old and over based on the highest diploma held is dominated by high school and above (53.98\% male and $47.30 \%$ female). According to Singal $[10,11]$ there was a relation between knowledge and the utilization of community health center by patients.

The second factor is the facilities and infrastructure in community health center, which is a supporting factor for patients in utilizing services from acommunity health center. Bsed on data obtained from Health Department for Banjarmasin City in 2019, there were several facilities and infrastructure. Facilities available in community health center are including 50-70 chairs, clean water sources, room layout, fan/air conditioner, TV, computer and printer, health related posters as media for informations attached on walls. While, infrastructures available are including community health center building and parking area for patient. According to Wulandari et al., [12] there was a relation between the availability of facility and infrastructure with community health center utilization by patients.

Apart from those two factors, the fourth factor, patient visit in utilizing community health center for treatment is also related with the requirements of health services. Service requirements in a health facility are including 5 particular criterias. One of the criterias is the accessibility of the location or place of community health center [13]. The accessibility of health facility is defined as the location of helath services that is easy to access with the available transportation, both in urban and rural areas. Based on data obtained, Banjarmasin Indah, S. Parman, and Alalak Tengah community health center are able to access with both 2 and 4 wheeled vehicles. According to Masitaet et al., [14] there was a relation between access and community health center utilization by patient when obtaining health services.

Therefore, based on above explanation, the candidate of researchers were interested in studying factors that related with outpatient treatment at 3 community health centers with the least BPJS participants in Banjarmasin City.

\section{METHODOLOGY}

This study was a quantitative study, with analytic observational study and conducted with cross-sectional design. This study will be conducted in community health center in BanjarmasinCity with the least patient visit, namely Banjarmasin Indah, S. Parman, and Alalak Twngah communityhealth centers during August to September 2020.

The population used in this study are all BPJS participants (Capitulation in June 2019) included in BPJS participant database in Banjarmasin's community healthcenters with the least patient visit (12.807 people from Banjarmasin Indah, 23.339 people from S. Parman and 61.109 people from Alalak Tengah). Total population used in this study are 97.225 people.

Sampling collecting technique used in this study is consecutive sampling with minimum sample of 96 people and added with $10 \%$ of it, hence become 106 people. Independent variables will be studied in this study are knowledge, facility and infrastructure, and accessibility. While, dependent variables are the utilization of community health centers by BPJS participants. Data will be analysed descriptively and analytically (univariate, bivariate, and multivariate).

Univariate analyses to describe data of each variables, bivariate analyses used chi square test with $95 \%$ confidence level, and multivariate analyses used logistic regression with $95 \%$ confidence level also.

\section{RESULTS}

From the results of bivariate analysis, knowledge, facility, infrastructure and accessibility to community health center havea significant relation with the utilization of community health center. The results of PR is 7.619 (CI 95\% 3.474-16.710), which means that respondents with good knowledge will use community health center 7,619 times more than respondents with lack of knowledge. The result of PR is 3.920 (CI 1.972-7.792), which means respondents who stated the facilities were good would use the community health center 3.920 timers greater than respondents who stated the facilities were not good enough. 
TABLE 1

THE RELATION BETWEEN KNOWLEDGE, FACILITY, INFRASTRUCTURE, AND ACCESSIBILITY

\begin{tabular}{|c|c|c|c|c|c|c|}
\hline \multirow{2}{*}{$\begin{array}{l}\text { Independent Variable } \\
\text { Knowledge }\end{array}$} & \multicolumn{4}{|c|}{ Community Health Center's Utilization } & \multirow{2}{*}{$p$-Value } & \multirow{2}{*}{ PR (95\% CI) } \\
\hline & & Yes & & No & & \\
\hline Good & 30 & $71.4 \%$ & 12 & $28.6 \%$ & 0.000 & $7.619(3.474-16.710)$ \\
\hline Poor & 6 & $9.4 \%$ & 58 & $90.6 \%$ & & \\
\hline \multicolumn{7}{|l|}{ Facility } \\
\hline Good & 28 & $56 \%$ & 22 & $44 \%$ & 0.000 & $3.920(1.972-7.792)$ \\
\hline Bad & 8 & $14.3 \%$ & 48 & $85.7 \%$ & & \\
\hline \multicolumn{7}{|l|}{ Infrastructure } \\
\hline Good & 21 & $56.8 \%$ & 16 & $43.2 \%$ & 0.001 & $2.611(1.539-4.430)$ \\
\hline Bad & 15 & $21.7 \%$ & 54 & $78.3 \%$ & & \\
\hline \multicolumn{7}{|l|}{ Accessibility } \\
\hline Accessible & 30 & $68.2 \%$ & 14 & $31.8 \%$ & 0,000 & $7.045(3.208-15.474)$ \\
\hline Unaccessible & 6 & $9.7 \%$ & 56 & $90.3 \%$ & & \\
\hline
\end{tabular}

PR result of 2.611 (CI 1.539-4.430) means respondents who stated the infrastructure was good would use the community health center 2,611 timers greater than respondents who stated the infrastructures were not good. PR result of 7.045 (CI 3.208-15.474) means respondents who stated the accessto community health center was good would use the community health center 7.045 timers greater than respondents who stated the access to the community health center was not easy.

TABLE 2

THE RESULT OF MULTIVARIATE STUDY

\begin{tabular}{lllll}
\hline \hline Variable & $\boldsymbol{p}$-Value & Exp (B) & $\mathbf{9 5 \%}$ CI & \\
\hline & & & Lower & Upper \\
\hline Knowledge & 0.000 & 22.999 & 4.463 & 118.526 \\
Facility & 0.004 & 11.699 & 2.222 & 61.606 \\
Infrastructure & 0.018 & 7.332 & 1.401 & 38.356 \\
Accessiibility & 0.000 & 33.192 & 5.865 & 187.834 \\
\hline \hline
\end{tabular}

The most dominant ndependent variable related to utilizing community health center is the accessibility $(p=0,000)$ with beta exponential value (Exp B) of 33,192.

\section{DISCUSSION}

Knowledge of community health center will change people's behavior in utilizing community health center services. Knowledge has a very important role because with the knowledge possessed by the community, an attitude will be formed and then followed with the action to choose good health services. Knwoledge is an experience gained by oneself or experiences obtained by others. Attitude depicts whether someone like or dislike a particular object. Attitude is often obtained from other's or onself's experiences [15].

According to studies conducted by Silitonga [16] and Sebayang [17] stated that there was a significant relation between knowledge and the utilization of health services. Se- bayang [17] stated that people that well-educated on JPKMM have a chance of 5.722 times greater to utilize community health center in obtaining health service compared to repondents with poor knowledge about it. A study conducted by Singal [10] stated that there was a realtion between knowledge with the utilization of community health center.

There are less seats (only 25 seats available) in Banjarmasin Indah community health center and that are already included with seats for drug queue. Several seats are also in poor condition or even cannot be used. Thus, sometimes many patients were forced to stand. Several medical instruments such as blood glucose kits and others are also lacking or even not available. Hence, causing heath services not optimal. Likewise, the availability of facilitiesat Banjarmasin Indah community health center is still lacking, the waiting room is arrow and cause many patients are waiting outsidethe room, the waiting room is also less comfortable because 
it doesn't have fans nor air conditionair so the room is hot. Medicine supplies often run out, this causes patients not to use the community healthcenter due to the lack of facilities. Alalak Tengah community health center is the most complete in term of its facilities due to it was being very recent built. Thus, the facilities are sytill complete and in good condition. All medical equipment is available and complete. The waiting room for patients for treatment as well as the waiting area for drugs are quite spacious. The waiting room is comfortable with adequate fans, so that the room is not hot. Medicines are always available. The availibilityof facilities causes patients to feel comfortable when seeking treatment and enjoy in utilizing community health center service. A study conducted by Wulandari [12] stated that there was a significant relation between facility awith the utilization of community health center $(p=0.025)$.

The infrastructure at the $\mathrm{S}$. Parman is not large enough but good incondition, the parking area is narrow so that if many patients seek treatment, people would park upto rhe road. Likewise, at Banjarmasin Indah, the infrastructure is still lacking, especially the narrow parking area, if there are lots of patients, the parking area would reachethe road and disturbs traffic. The parking areais only suitable for parking for 2-wheeled vehicles with a total of about 10 vehicles. Meanwhile, Alalak Tengah's parking area also not too large, only for 2-wheeled vehicles around 10-20 vehicles. it can be concluded that all of those 3 community health centers have not too large parking area and only enough for several 2-wheeled vehicles parking space. All community health centers have 1 unit of ambulance. A study conducted by Wulandari [12] stated that there was a significant relation between infrastructure with the utilization of community health center $(p=0.025)$.

Facilities consist of infrastructure, can support behaviour of community. Complete facilities can make community believe and comfort to have health service there. Facilities can support health and clean behaviour and change behaviour movement as physical environment [18].

Basedon the observations, the access to S. Parman is rather difficult because it cannot be reached by publictransportation, patients who wants to seek treatment there musthave their own vehicle or be accompanied by their family or using online applications such as Grab or GoJek, although in reality there were many people there who do not own those applications. Other than that, the community health center is located in low area. Thus, when the tide was high, the road to the health center wiould be flooded and difficult to pass by with vehicle or even on foot. Difficult access also occurs at Banjarmasi Indah, due to no public transportation.
Patients who seek treatment must use their own vehicles or using ojek service. However, people who live near the health center can walk to access thehealth center because the road is in good condition. Likewise, Alalak Tengah's public transportation is not available, patients who seek treatment must walkor use their own vehicle or use ojek service. Based on that, it can be concluded that all of those 3 community health centers are not easy to access due to the lack of public transportation.

People prefer to utilize infrastructure around their neighborhood compared to respondents who lives far away. Expensive and complicated transportation fee also become their consideration to choose other community health center with cheaper and easier mode of transportation fee, even if they had to spend more money health services. As an example, people would prefer to seek treatment in nearby health facility due to easy to access, time-efficient because shorter queue and open 24 hours.

According to Masita [14], the accessibility is access that must be reached by people, free from obstacles geographically, socially, economically, organization and languagewise. Based on bivariate analysis result showed that there was a relation between accessibility with the utilization of community health center in Kagok health center $(p=0.000)$. The most dominant variable related with the utilization of community halth center is the accessibility to health center. Easy access to health center will ease people to utilize health center. Good knowledge will cause people to find health center that are easy to access with cheaper transportation fee and also considering its facility and infrastructure. Based on data obtained, all of those 3 community health centers are not available for 24 hours. Thus, not everyone able to get treatment when the health center is closed.

Access to health facilities are various based on situation and geographics condition. It is challenge in giving health facilities more distributed. Without easy access, community will be difficult to get health services mostly poor community. People who live near health facilities wiil get health services easier than far away [19]. This research is in line with Karman [20] that stated easy access to health facilities was dominant variable in getting public health services $(p=$ 0.000).

\section{CONCLUSION}

This study concluded that:

1. There was a relation between level of knowledge of BPJS participants with the utilization of community health center by BPJS participants in working area of Banjarmasin City's 
community health center (Banjarmasin Indah, S. Parman dan Alalak Tengah) in 2020.

2. There was a relation between facility with the utilization of community health center by BPJS participants in working area of Banjarmasin City's community health center (Banjarmasin Indah, S. Parman dan Alalak Tengah) in 2020.

3. There was a relation between infrastructure with the utilization of community health center by BPJS participants in working area of Banjarmasin City's community health center (Banjarmasin Indah, S. Parman dan Alalak Tengah) in 2020.
4. There was a relation between level of knowledge of BPJS participants, facility, infrastructure, accessibility with the utilization of community health center by BPJS participants in working area of Banjarmasin City's community health center (Banjarmasin Indah, S. Parman dan Alalak Tengah) in 2020. The accessibility is the most dominant variable related to the utilization of community health center.

\section{LIMITATIONS OF THE STUDY}

Limitations of this study was pandemic situation that made limit to get more samples and more locations.

\section{REFERENCES}

[1] Health Department. Primary health care systems (Primasys); 2016. Available from: https://bit.ly/3bv8lYC.

[2] Abu HO, Goldberg RJ. Make scientific reading great and more meaningful again: Reappraisal of the traditional P value in modern-day clinical research and practice. The American Journal of Medicine. 2019;133(1):1-23. doi: https://doi. org/10.1016/j.amjmed.2019.05.054.

[3] Health Department. Number of Public Health Centres per-June 2015 Based On Province and Regency/City. Health Department. Jakarta, Indonesia; 2016.

[4] Badan Penyelenggaraan Jaminan Sosial. Service Guide for BPJS Health Participants; 2013. Available from: https://bit. ly/3chmzv9.

[5] Wulandari C, Saptaputra S, et al. Factors related to the utilization of health services at the UPTD Langara Puskesmas, Wawonii Barat Subdistrict, Konawe Archipelago Regency in 2016. (Jurnal Ilmiah Mahasiswa Kesehatan Masyarakat). 2016;1(3):56-65. doi: http://dx.doi.org/10.37887/jimkesmas.v1i3.1087.

[6] Braun V, Götz F, Schultz JE, Wohlleben W. The bacterial cell envelope: Structure, function, and infection interface. International Journal of Medical Microbiology. 2014;305(2):175-177. doi: https://doi.org/10.1016/j.ijmm.2014.12. 003.

[7] Lestari T. A collection of theories for literature review of health research. Yogyakarta, Indonesia: Nuha Medika; 2015.

[8] Hurtado R, Maturrano L, Azevedo V, Aburjaile F. Pathogenomics insights for understanding Pasteurella multocida adaptation. International Journal of Medical Microbiology. 2020;310(4):151-177. doi: https://doi.org/10.1016/j.ijmm. 2020.151417.

[9] Sungkhapong T, Prommete P, Martkoksoong N, Kittichottipanich B. The health behaviors' modification for controlling and prevention of diabetes mellitus by using promise model at premruthai pravate community Bangkok. Journal of Advances in Health and Medical Sciences. 2016;2(3):97-101. doi: https://doi.org/10.20474/jahms2.3.3.

[10] Singal HI, Kandou GD, Rumayar AA. The relationship between knowledge, attitudes and income with the use of the puskesmas by the people of Kima Bajo village, wori sub-district. Kesmas. 2019;7(5):34-40.

[11] Prabsangob K. Relationships of health literacy diabetes knowledge and social support to self-care behavior among type 2 diabetic patients. International Journal of Health and Medical Sciences. 2016;2(3):68-72. doi: https://doi.org/ 10.20469/ijhms.2.30005-3.

[12] Wulandari SA. The effect of the use of endorsements on the sales turnover of online shop businesses in Palangka Raya. IAIN Palangka Raya, Palangkaraya, Indonesia; 2017.

[13] Surahman S Supardi. Public Health Sciences PKM. Jakarta, Indonesia: Selatan Press; 2016.

[14] Masita A, Yuniar N, Lisnawaty L. Factors Related to the Utilization of Health Services in the Community of Tanailandu Village in the Work Area of the Kanapa-Napa Community Health Center, Mawasangka District, Central Buton Regency, 2015. Jurnal Ilmiah Mahasiswa Kesehatan Masyarakat. 2017;1(3):12-20. doi: http://dx.doi.org/10.37887/jimkesmas. v1i3.1246.

[15] Notoatmodjo S. Health promotion and health behavior. Jakarta, Indoneisa: Rineka Cipta; 2012.

[16] Silitonga J Hetti. Utilization of Medical Services at Puskesmas by Poor Families Targeted by the JPS-BK Program in Pulau Pinang District. Gadjah Mada University, Yogyakarta, Indonesia; 2001. 
[17] Sebayang R. Analysis of the Utilization of Basic Health Services at Puskesmas by Poor Families Participating in the Maintenance Insurance for the Poor (JPKMM) in the Warungkondang District, Cianjur Regency. University of Indonesia, Depok, Indonesia; 2006.

[18] Notoatmodjo S. Health Research Method. Jakarta, Indonesia: Rineka Cipta; 2010.

[19] Suwarning W. E-health mobile agent for immunization monitoring; 2013. Available from: https://bit.ly/3rBcRu9.

[20] Karman H. Factors related with health services using by coastal community in Bungin Permai Village Tinanggea Subregency South Konawe Regency in 2016. Science Journal of Public Health Students. 2016;1(3):45-60. 